\title{
Best Practice of Science Learning (Case of Islamic Senior High School 4 Jakarta)
}

\author{
$1^{\text {st }}$ Abdul Kadir Ahmad ${ }^{1}, 2^{\text {nd }}$ Sumarni $^{2}, 3^{\text {rd }}$ Opik AbdurrahmanTaufik ${ }^{3}, 4^{\text {th }}$ Kun Mardiwati \\ Rahayu $^{4}$ \\ \{abduladir76@gmail.com¹, marni-chi@gmail.com², taufikrachman74@gmail.com³, dan \\ kun_rahayu@uai.ac.id $\left.{ }^{4}\right\}$
}

Puslitbang Pendidikan Agama dan Keagamaan ${ }^{1}$, Puslitbang Pendidikan Agama dan Keagamaan 2, Puslitbang Pendidikan Agama dan Keagamaan ${ }^{3}$, Universitas AL Azhar Indonesia ${ }^{4}$

\begin{abstract}
This paper is the result of research conducted on students of Madrasah Aliyah Negeri 4 Jakarta. This study uses a quantitative approach with qualitative descriptive methods. The findings of the study show that the implementation of science learning at MAN 4 Jakarta is well implemented and supported by supporting factors, including curriculum management, student affairs, human resources, financing, and infrastructure available at MAN 4 Jakarta is sufficient to carry out supporting science learning. accomplishment of science material completeness and achieving scientific academic and non-academic achievements. These findings indicate that the development of a scientific culture needs to be carried out as a whole, in the sense that all elements of the madrasah community need to be involved. The success of these superior programs requires cooperation or partnerships with various other institutions / agencies that are related to the superior programs developed in Madrasahs..
\end{abstract}

Keywords: Best Practice, madrasa, Science Learning.

\section{Introduction}

a. Research Background

Science learning at Madrasah Aliyah (MA) must be carried out holistically, systematically and integrally, and is expected to be able to integrate cognitive, affective and psychomotor achievement targets. Ideally, science learning in MA emphasizes more on appreciation, internalization, and the ability to face 21 st century skills (critical thinking, problem solving, creativity, and collaboration) in everyday life. Guiding the results of cognitive, affective and psychomotor achievements is very important, so that students have knowledge, tendencies, and scientific behavior (critical, thinking in everyday life) (Amrullah (2013),

However, science learning in MA has been criticized and considered unsuccessful, if the measuring instrument used as a reference is a standard combination of cognitive, affective and psychomotor achievements.

From these problems, this research becomes important to reveal how the strengthening of science learning in madrasas, especially Madrasah Aliyah (besides MAN Insan Cendikia) as a best practice that will become a model to be socialized to other madrasas in general. It is hoped that the best practices of a small number of madrasah can transmit 
superior values and produce high-achieving madrasah students evenly and widely on a national scale.

\section{b. Problem Formulation}

The advantages of science learning at some of these madrasas need to be benchmarked so that they become a rule-model which can then be adopted and adapted in strengthening science learning and socialized to other madrasas, so that all madrasas can carry out science learning with superior results.

Based on this, research is needed to determine how the system and the impact of science learning activities on the development of MAN 4 Jakarta.

c. Objectives and Benefits of Research

This study aims to explore the advantages of the science learning model in Madrasah Aliyah as best practice in terms of context, input, process, and output aspects of science learning on the quality of results and student further study and / or the world of work.

The results of this study are expected to be used as input for the Directorate General of Islamic Education at the Ministry of Religion, especially the KSKK Directorate in making policies to improve the quality and competitiveness of madrasas in the field of science. For madrasah, the results of this study can be used as input and reference in an effort to improve or improve the quality and competitiveness of science learning in madrasah

\section{d. Conceptual Study}

Best practice comes from English which means best practice, which is an idea or idea regarding a technique, method, process, activity, intensive or reward that is more effective in achieving extraordinary success compared to other techniques, methods, processes (Cita Indira, 2014). Ideas or ideas, with appropriate monitoring and testing, can produce the expected results with fewer problems and unexpected complications Apandi (2019).

Madrasahs in the law are stated to be part of national education which is equal to schools, namely "basic education in the form of elementary schools (SD) and Madrasah Ibtidaiyah (MI) or other equivalent forms as well as junior high schools (SMP) and Madrasah Tsanawiyah (MTs) ) or other equivalent forms, while secondary education takes the form of Senior High Schools (SMA) and Madrasah Aliyah (MA) (Law Number 20 of 2003).

Science learning best practices referred to in this study are best learning practices that are carried out repeatedly, continuously, and consistently in scientific learning activities so as to produce the best results and make the madrasa community and madrasa community proud. These results can be shown based on academic achievements, such as the highest final exam or national examination scores (intracurricular), and extracurricular activities such as participating in various science competitions and obtaining a number of competitions, and / or conducting scientific research activities and producing scientific works that are included in competitions / championships. National level

e. Research Methodology

The research method used is descriptive qualitative method. This method is used to describe a phenomenon, events, and events that occur in the present. The analysis technique used is descriptive qualitative, which is to fully explain the management of 
inclusive education in madrasah which is based on certain criteria and indicators Wahyuni (2012) and Sukmadinata (2011). The data were obtained through interviews, particularly with the Head of Madrasah, Head of Administration, and Chair of the Madrasah Committee. Supporting data was extracted from teachers, supervisors, and students in the target madrasah (MAN 4 Jakarta).

\section{MADRASAH'S PROFILE}

a. Madrasa History, Vision, Mission, Goals and Target of Madrasah Madrasah Aliyah Negeri (MAN) 4 Jakarta is a high school level education institution with a global perspective with Islamic characteristics. MAN 4 Jakarta refers to the national need for superior human resources in the mastery of Science Technology (IPTEK) and equipped with Faith and Faith (IMTAK) as Madrasah Aliyah which was founded in 1992 as a result of the change of function from PGAN 28 in accordance with the Decree of the Minister of Religion of the Republic of Indonesia number 64 of 1992 dated April 29, 1992. In 1998 MAN 4 Jakarta for its various achievements so that it was designated as a MAN Model for DKI Jakarta by the Minister of Religion of the Republic of Indonesia in accordance with the Decree of the Director General of Islamic Bodybuilding No.E.1V / PP.00.6 / Kep / 17.A / 1998 dated February 20, 1998. And in 2008 MAN 4 Jakarta became the National Standard Madrasah (MSN) from 38 MAN Models throughout Indonesia, along with the development of the world of education and the National Education System Law, then in 2010 MAN 4 Jakarta was enacted as an International Standard Madrasah (RMBI) Pioneer in accordance with the Decree of the Head of the Regional Office of the Ministry of Religion, DKI Jakarta Province. However, according to the Decision of the Constitutional Court (MK) regarding International Standard School Stubs (RSBI), now MAN 4 Jakarta is no longer the status of International Standard Madrasah Stubs (RMBI). However, MAN 4 Jakarta still maintains and guarantees the quality and quality of education in order to remain competitive with other schools, including establishing sister schools with Narrogin Senior High School, Western Australia and universities in Tokyo, Japan(Khairani: July 2020).

Now, MAN 4 Jakarta has been certified ISO 9001: 2015 which is a renual of the previous certification, namely ISO 9001: 2008. Geographically, MAN 4 is located on Jalan Ciputat Raya, Pondok Pinang, Kebayoran Lama, South Jakarta. Its location is very strategic, which is on the side of the outer ring road of the TB toll road. Simatupang, South Jakarta which is close to the elite area of Pondok Indah, and not far from the Syarif Hidayatullah State Islamic University Jakarta. MAN 4 Jakarta has a land area of 21,980 $\mathrm{m} 2$ and a building area of $7,317 \mathrm{~m} 2$.

b. Condition of Teachers and Students in General (Qualification and Competence)

The number of teachers in MAN 4 Jakarta is 109 teachers, consisting of 55 male teachers, 59 female teachers, 78 certified teachers and 36 non-certified teachers. While the total number of students is 985 students, consisting of 403 male students and 582 female students. Based on the results of the questionnaire, it is known that the average choice to go to school at MAN 4 Jakarta is their own desire and is supported by their parents, with several considerations, namely the achievements of MAN 4 Jakarta which are not only 
superior in the field of religion, but also in general materials including science. And this is supported by very adequate educational facilities, competent educators and educational staff, varied extracurricular choices, there is a boarding school program, has excellent classes, and is rich in academic and non-academic achievements. Public interest in continuing education at MAN 4 Jakarta every year increases, with just a few days, the registration quota has been fulfilled

c. Facilities and Financing

Madrasa facilities consist of: hydroponic vegetable garden, music room, science laboratory, basketball court (indoor and outdoor), football field (indoor and outdoor), badminton court, futsal court, mosque, madrasa canteen, library, student work corner, hall and meeting room

The facilities and infrastructure owned by MAN 4 Jakarta to support the development of education, namely: study rooms equipped with $\mathrm{AC}$ and LCD projectors, science laboratories (physics, chemistry and biology), language laboratories, computer laboratories, male female dormitories, mosques, madrasa cooperatives, an integrated learning center (PPT) designed for learning by sport and science, including a swimming pool, library room, hotspot area, living pharmacy garden, multimedia room, shared learning resource center, and so on (Endah: July 2020).

d. Madrasa culture

The culture and climate developed by MAN 4 Jakarta is to build a sense of togetherness that can trigger the development of self-confidence and creativity of all madrasa citizens, including all students. Culture is carried out throughout the time studying at the madrasa. All teachers are assigned to develop the habituation program established by the madrasah. The assessment of this activity is qualitative. The potential, expressions, behavior, and psychological conditions of students are portfolios used for assessment.

Among the culture and climate of the madrasa are (Lisnur: July 2020):

1) Change Your Life with "RKMS"

- Religion for peaceful life: Duha prayer and hajat prayer, Tadarus, Tahsin and Tahfidz Alquran, congregational prayer, Sadaqah, Kultum and qira'ah

- Knowledge For International Communication and Understanding: Arabic and English Contest, English Correspondence, AZHARIYAH (Bulletin), Science Olympiad, Speech, Fahmil and Syarhil Quran, Journalism

- Music for a beautiful life: PENtaS SeNI, MANIZ Islamic Music Group, Marawis, Pencak Silat, Saman Dance, Hadroh, Graphic Design.

- Sport for a vital mind and body: Basket ball, Futsal, Vollyball, Table Tennis, Badminton, and so on

2) Cultivate 11 golden cultures of MAN 4 Jakarta: Smile, Greetings, Greetings, Courtesy, Kiss Hands, Queue, Neat, Clean, Thrifty, Honest, Listening when other people talk

3) Publishing 11 Golden Words: Greetings, Thank you, Sorry, Please, Congratulations, Can you help, May, We Can! (Yel-Yel), Hopefully, in my opinion, Madrasas are better, Madrasas are better

4) Every day to memorize and memorize the Qur'an, especially the local content of the material of the al-Qur'an tahfidz. Memorizing the Qur'an is a requirement for taking midterm and semester exams. 
5) Parents of students are involved in various activities, such as creating rules, controlling their child's learning development, enforcing discipline in madrasas, regular meetings between parents and madrasah, providing material contributions.

6) Self-development for Teachers and Students, schedule for employee teachers: 1). Sufism Studies: Every Wednesday by Prof. DR. Nasarudin Umar Imam Istiqlal Mosque. 2). Tafsir Study: Every Thursday by Ustad Hasbi Badiuzzaman's Tafsir Study. 3). Dzikir Muhasabah: Every Friday by Ustad Zubair. Meanwhile, the student schedule consists of morning habituation - tadarus tahfiz dhuha - literacy, as well as memorizing deposits with Syech Ahmad from Cairo, Egypt

e. Madrasa characteristics

The characteristics of MAN 4 Jakarta are (Liznur "i: July 2020):

1) The thabur shabah program, which is the morning activity before teaching and learning activities in class, starting from 06.30 to the hour. 07.00.

2) MAN 4 Jakarta has used an international quality management system that we know as ISO 9001: 2015 certification (International Standard of Organization).

3) Art and culture exhibition is an annual event that is held at least once a year.

4) Providing breakfast and lunch for all students under the supervision of a nutritionist.

\section{CONTEXT OF SCIENCE LEARNING}

a. Background Strengthening Science Learning in Madrasah

There are several things behind the strengthening of science learning at MAN 4 Jakarta, namely:

1) Location and infrastructure at MAN 4 Jakarta. A strategic location supported by complete infrastructure enables each student to learn actively, such as observing, exploring, reasoning, trying, concluding, and communicating various findings.

2) People's choice of education has changed. Previously, madrasas were only required to produce graduates who were more proficient in religious knowledge. Currently, parents want madrasas to be able to produce graduates who master both religion (faith and piety) and science and technology.

3) MAN 4 Jakarta has good input and output, through a fairly strict selection. The average desire to continue education at MAN 4 Jakarta is their own willingness which is fully supported by their parents. The madrasa has implemented the curriculum in various ways, including holding TOEFL training at the UI Language Institute for English teachers and students, bringing in native English speakers from the Jakarta International School, bringing in Japanese language native speakers from the Japane Foundation (JF), participants Class XII students are given certified applied computer skills equivalent to D-1, issued by the Central Informatics Institute, carry out matriculation of Mathematics, English, Arabic and PAI subjects, to class X students, facilitate UN and SPMB-oriented learning, conduct team learning teaching by involving lecturers from FMIPA UI in the field of Mathematics and Natural Sciences in class X Featured Bilingual

b. Science Learning Policy in Madrasah 
Strengthening the Science Subject Teacher Deliberation (MGMP) institution is one of the policies implemented in MAN 4 Jakarta in developing science learning in madrasas. With this institutional strengthening, the entire academic community of MAN 4 Jakarta will recognize that learning science is an effort to improve the quality of MAN 4 Jakarta. Among the methods used to strengthen science learning (Aceng: July 2020);

1) All teachers participated in strengthening science learning. Learning with this method can be said to be a method that combines the inquiry method and the discovery method. The essence of science learning is that the teacher functions more to guide, direct, train and familiarize students to recognize and determine problems that are relevant to the subject being studied;

2) Development through extracurricular activities, namely placing the type of research activity as an option that can be followed by students. Because science extracurricular activities are an activity of choice, enthusiasts in this extracurricular activity are more followed by students who are truly interested in science. This extracurricular science activity is designed in such a way as to become a superior activity;

3) Establish a MGMP forum for all science subjects. This is done through a decree from the madrasah management, so that the MGMP science forum has a very clear legal force. Besides that, the decision of the head of the madrasah will have an influence on science learning activities. This influence can be in the form of funding and special facilities for managing the MGMP science forum by the madrasah committee;

4) Increasing the professionalism of teaching staff and education staff. For this reason, MAN 4 Jakarta collaborates with various agencies that are competent with education. Among them, language teachers (Arabic, English, German, and Mandarin) attended TOEFL training at the UI and UIN Ciputat language institutions. The UI language institute certifies TOEFL for students. At the beginning of each academic year, class $\mathrm{X}$ students are given a psychological test by the Psychology Institute. Bringing native Arabic speakers and religious knowledge from Al Azhar Asy Syarif Egypt, as well as Japanese native speakers from the Japane Foundation (JF), and so on;

5) Very strict selection to select students who are accepted at MAN 4 Jakarta. This selection is carried out to select students who have good academic abilities. Apart from going through a written test, as in general student selection is carried out at other madrasas, selection is also carried out through a portfolio. In this case the madrasah will take students who have proven to have achievements in competitions of innovative works or scientific writing, as evidenced by a certificate or acknowledgment letter as outstanding students;

6) The recruitment of talented coaches / trainers in science can be done through selection. The trainer is directed to people who already have experience in developing science;

7) Provision of facilities and centers for science learning activities such as libraries and adequate laboratories as centers for student and teacher literature studies;

8) Collaborative networks with institutions or parties that have an interest in science development, such as alumni forums and universities to provide science learning guidance to teachers or students.

c. Motivation and Goals of Strengthening Science Learning

Based on the results of observations and interviews with Mr. Aceng Sholihan as the head of the Madrasah, there are several excellent science learning programs that are launched to shape character and create madrasah characteristics, namely (Aceng: July 2020); 
1) Application of the tradition of learning science for all subjects and

2) Application of science extracurricular programs.

3) Restoring the glory of science among Muslim scientists

4) Affirmation of the position of MAN 4 Jakarta as a leading madrasa that positions religious and general subjects as important

These four programs are formulated after conducting several analyzes on the development of superior madrasah, which require several excellent programs that must exist and are programmed as one of the conditions in developing superior madrasah. This analysis is carried out by looking at the strengths, weaknesses, challenges and opportunities in the future in order to become a reference for the preparation of these programs and to see opportunities in the future to see the increasingly advanced times.

\section{INPUTS OF SCIENCE LEARNING}

a. Availability of Curriculum

Curriculum development in the administration of science madrasas is very important, so that science is not just a partial learning activity, but a curriculum that is taught. The curriculum taught at MAN 4 Jakarta is divided into three subjects, namely general subjects, religion and local content, while for the development of students' interests and talents, it is carried out through extracurricular activities that are non-academic and that support academically. MAN 4 Jakarta in improving the services of various students, has opened several class programs, namely (Fitri: July 2020):

1) Cambridge curriculum classes:

- Specialization in Science: Physics, Biology, Chemistry, English, and Mathematics. For cross-interest subjects, a Japanese language subject is provided and a cross-interest subject is provided.

- Specialization in Social Studies: Economics, Sociology, Geography, English, and Mathematics. For cross-interest subjects, a Mandarin subject is provided and a cross-interest subject is provided.

- All learning uses English and the learning materials use the Cambridge curriculum.

2) The Olympic curriculum, namely deepening the material, UTBK material, training on UN questions, guidance from UI / ITB / UIN, training on OSN questions, and participating in competitions

The above subjects continue until class XII, and students in the Olympics class are required to enter the dormitory, with the target that all class X, XI, and XII subject matter can be completed in semester IV (class XI).

3) The Technopreneur Curriculum, namely the Entrepreneurship Workshop (PKWU) Economy, ICT guidance, and Multimatics institutions (Technopreneur Certification) This class is directed so that students have skills and have an interpreter spirit that can produce useful products with IT-based characteristics and are recognized. They are trained by actors who already understand very well about tecnopreneurs.

b. Condition of Educators, Education Personnel (Science) and Students 
From the information data of MAN 4 Jakarta, the number of teachers who teach science subjects is 40 people, namely 12 mathematics teachers, 5 chemistry teachers, 5 biology people, 4 physics people, 6 economics, 3 geography, 3 sociology, and 2 history. person. The students' eyes they are able to match their educational background.

In addition, teachers are given the opportunity to develop themselves by taking part in the MGMP (Subject Teacher Conference) which is part of the MGMP MA (Kemenag) and the MGMP SMA (Diknas).

c. Support for Pre-Facilities Science learning facilities

MAN 4 Jakarta already has adequate facilities and infrastructure to support the implementation of the educational process. Facilities such as laboratories, computer equipment, LCD and air conditioning - each class -, laptops, printers, scanners, and furniture. Meanwhile, infrastructure can be divided into two, namely building infrastructure and public infrastructure. Building infrastructure includes land and buildings used for study rooms, office spaces, leadership rooms, teachers' rooms, multimedia rooms, meeting rooms, laboratory rooms, library rooms, gardens, public and welfare facilities, mosques, sports and arts facilities and dormitories. learners. Furthermore, public infrastructure in the form of water, sanitation, drainage, electricity, communication networks, internet networks, CCTV, transportation, parking lots, and parks. The area of land owned by MAN 4 Jakarta is 21,980 M2 with the status of Ownership Rights in the name of the Ministry of Religion in 1982.

d. Source of Funds for Science Learning

Funding for MAN 4 Jakarta programs / activities comes from two sources, namely: the APBN through the disbursement of School Operational Assistance (BOS) and through the Budget Implementation List (DIPA) issued by the Ministry of Religion, as well as the South Jakarta City APBD which is called the Operational Cost of Operators (BOP).

For programs that cannot be funded by the APBN or APBD, the program will be submitted to the committee (Khairani: July 2020).

\section{SCIENCE LEARNING PROCESS}

Science learning activities at MAN 4 Jakarta are divided into two activities, namely intracurricular and extracurricular activities (Fitri: July 2020):

a. Planning Science Learning Activities

Learning planning that describes the planning process, evaluating learning outcomes, and monitoring the learning process for the implementation of an effective and efficient learning process. Every teacher is obliged to prepare a lesson plan.

1) Science Intracurricular Planning

In the preparation of the RPP in collaboration with madrasah MGMPs which are adjusted to the indicators in Permendikbud No. 22 of 2018 concerning process standards. The lesson plan prepared by the teacher has facilitated students to carry out learning with a scientific approach which is the emphasis of the 2013 curriculum.

2) Science Extracurricular Planning

Extracurricular activity planning contains the following element: 
a) Preparation of extracurricular plans and programs must be seen from the point of view of their benefits as well as their value.

b) The coach / trainer must have competence in the extracurricular field that he / she handles, and for management handled by the students themselves with the aim of assigning responsibility and independence.

c) The time and place for activities are carried out in accordance with the situation and conditions of the activities so that they are effective and right on target, for that extracurricular activities at MAN 4 Jakarta are carried out on Fridays and Saturdays so as not to interfere with compulsory subjects at the madrasa.

d) Paying attention to the basic needs of students as well as other needs based on extracurricular types and programs, of course extracurricular activities at MAN 4 Jakarta have the principle that they must be strongly based in a religious perspective.

e) Manage extracurricular activity funds. The extracurricular members took the initiative to form their own budget program which they named DANUS (Business Fund). For the management of funds for each extracurricular at MAN 4 Jakarta, namely by being given an order through the principle of selection of available work programs and the amount of funds required.

f) The extracurricular committee functions in planning activities both inside and outside the madrasah.

b. Implementation of Science Learning

1) Implementation of Science Intracurricular Activities

MAN 4 Jakarta in learning develops Cambridge class programs, Olympic classes, and Regular classes. In the regular class, the advantages of each specialization are also developed. The difference between the Olympic class program and Cambridge and the regular class is that the Olympic class all students are boarded at the madrasa. Specializations that are developed on a regular basis are Specialization in Mathematics and Natural Sciences, Specialization in Social Studies, Specialization in Religion, and Specialization in Language. To develop their academic competence, students must follow the Academic Extracurricular Program of their choice. This activity is an activity of guidance, tutorials, and development of student competencies in mathematics, physics, chemistry, and biology. The tutors / extracurricular teachers are outside teachers who have competence in coaching the Olympics (preferably have been involved in the competition), MAN 4 Jakarta teachers are positioned as companions. The extracurricular program is implemented to deliver students achievement in various academic events, such as the Olympics (from PT), KSM (Madrasah Science Competencies), and OSN (National Science Olympiad). Several students in this program have achieved achievements both at the municipal and provincial levels.

In general, educational practice uses several learning methods that are able to facilitate students' natural thinking and construct high-order thinking skills, namely: integrated learning, project based learning, discovery / inquiry learning, problem based learning, cooperative learning, and moving classes.

2) Implementation of Extracurricular Activities

Permendikbud No. 62/2014 on Extracurricular activities, a madrasa will be more stable and more confident in the implementation and implementation of 
extracurricular activities. Described in the attachment to Permendikbud Number 62 of 2014 concerning details of extracurricular activities, including compulsory extracurricular activities, namely scouts and optional extracurricular activities. For the Scout extracurricular, it is mandatory for grade X students to participate in the extracurricular activity and for the extracurricular choice, at least one student must have one at the madrasa. Extracurricular activities at MAN 4 Jakarta are held on Friday and Saturday. On Fridays, extracurricular activities are carried out after school, namely at 15.30-17.00, while on Saturdays, extracurricular activities are held at $07.30-11.30$.

This activity can develop students' ideas and creativity through quality objectives, work programs and activity steps that they make through this activity as well as many benefits for students in shaping student character including having independence and ability in religious life, having social, cultural and natural surroundings, and can instill an attitude as good and responsible citizens through various positive activities.

c. Assessment of Learning Science

The assessment system for intracurricular activities refers to the assessment standards set by the government, which is based on 21 st century skills (critical thinking, problem solving, creativity, innovation, communication, and collaboration). For students in Cambridge and Olympics classes the problem is directed to the Hots questions. Meanwhile, extracurricular activities at MAN 4 Jakarta emphasize activities (attendance), achievements, cooperation and independence. The evaluation instrument at MAN 4 Jakarta in the implementation of extracurricular programs is carried out routinely, both between the head of the madrasah in planning, coordinating and managing all available resources, the student council supervisor and the extracurricular coach.

\section{CLOSING}

a. Conclusion

a) The implementation of science learning at MAN 4 Jakarta is carried out well and is supported by supporting factors, including curriculum management, student affairs, Human Resources (HR), financing, and the infrastructure available at MAN 4 Jakarta is sufficient to carry out supporting science learning. achievement of science material completeness and academic and non-academic scientific achievements.

b) MAN 4 Jakarta in improving science learning services for various students, has opened several class programs, namely:

1) Cambridge curriculum class for Science specialization and Social Science specialization. Cambridge class students are entitled to a Cambridge diploma which is recognized by developed countries. Learning and evaluation materials are directed towards 21 st century competencies, namely critical thinking and problem solving, creativity and innovation, communication, and collaboration.

2) Olympic curriculum class with an emphasis on deepening the material, UTBK material, UN question practice, guidance from UI / ITB / UIN, training on 
OSN questions, and other Olympics. Olympics class students are required to enter the dormitory, with the target that all class X, XI, and XII subject matter can be completed in semester IV (class XI). And in class XII they are more focused on deepening the material that is usually contested.

3) Technopreneur class, exploration of economic entrepreneurship (PKWU) materials, ICT guidance, Multimatics institutes (Technopreneur certification). This class is directed so that students have skills and have an interpreter spirit that can produce useful products with IT-based characteristics and are recognized

c) The profile of the management of science learning at MAN 4 Jakarta, namely, First, for the aspect of learning planning, it was found that the preparation process began with socialization by the head of the madrasah, then a workshop was carried out followed by technical guidance, as well as discussions between subject teachers, then the teacher made the preparation of learning tools. Second, for the aspect of implementing learning, it is informed that there are teachers who teach based on the lesson plans. There is also a learning method with concept explanations and question exercises as the teacher's effort to increase student activity. Third, for the learning assessment aspect, it was found that the average teacher had referred to the assessment standards set by the government, which were based on 21 st century skills (critical thinking, problem solving, creativity, innovation, communication, and collaboration).

b. Recommendations

1) The development of a scientific culture needs to be carried out as a whole, in the sense that all elements of the madrasa community need to be involved. And that also means that all subjects in the learning process use scientific methods.

2) The success of these superior programs requires cooperation or partnerships with various other institutions / agencies that are related to the superior programs developed at Madrasah Aliyah. The form of cooperation or partnership carried out is related to the procurement of experts / experts, supply of program materials, funding, involvement in training education and so on.

3) Management of science madrasahs can be done using a variety of strategic approaches, including; 1) include science development programs in madrasah strategic planning; 2). Formalizing science working groups through the decree of the madrasah head; 3 ). Conducting selective recruitment by giving rewards to candidates who have performed well; 4). Enter science subjects through intracurricular; 5). Carry out special science guidance activities; 6). Developing a center of exelence in the field of science through the use of laboratories and libraries. 7). Develop scientific development collaborative networks with universities and research institutions; 8). Active participation in every science competition competition event; 9). Strengthening science infrastructure; 10). Science development team development and Olympic competitions through extracurricular activities

\section{References}


[1] Kemenag Luncurkan Program Madrasah Riset: Amrullah, A. (2013), Republika.co.id. Available at: https://www.republika.co.id/berita/duni a-islam/islamnusantara/13/09/04/mskqz4kemenagluncurkan-program-madrasah-riset (Accessed: 2 June 2019).

[2] Best-Practices Pendekatan Saintifik pada Pembelajaran Kimia di SMA Negeri 4 Sampit: Cita Indira, Jurnal Kaunia Vol. X No. 2, Oktober 2014/1435: 141-151ISSN 1829-5266 (print)ISSN 2301-8550 (online: https://media.neliti.com/media/publications/103740-ID-best-practicespendekatan-saintifik-pada.pdf), diakses pada 10-05-2020

[3] Interview with Aceng Sholihin, headmaster, In Jakarta, 7 July 2020

[4] Interview with Khairani, head of administration, In Jakarta, 7 July 2020

[5] Interview with Fitri Sulastri, deputy principal of the curriculum section of the madrasa, In Jakarta, 8 July 2020

[6] Interview with Lisnur Azizah, deputy principal of student affairs, In Jakarta, 8 July 2020

[7] Interview with Endah Umayah, deputy head of the madrasa for public relations, In Jakarta, 9 July 2020

[8] MAN 4 Kemenag, Sejarah Singkat MAN 4 Jakarta, 8 Juli 2020 on 11.45

[9] Pendidikan Kejar Nomor 1. Madrasah Pun Berbasis Riset: Rahardjo, A., Republik.co.id. Available at: $\quad$ https://www.republika.co.id/berita/pendidikan/eduaction/13/02/01/mhhiwskejar-nomor-1madrasah-pun-berbasis-riset, (2013)

[10] Metode Penelitian Pendidikan: Sukmadinata, N.S. (Cet ke-7). Bandung: PT. Remaja Rosdakarya, (2011)

[11] Undang-Undang Nomor 20 Tahun 2003 tentang Sistem Pendidikan Nasional 